\title{
Postpartum Hemorrhage: Kegawatdaruratan dalam Persalinan Ibu Hamil
}

\author{
Ni Putu Narithya Julieta ${ }^{1}$, Made Kurnia Widiastuti Giri ${ }^{2}$ \\ ${ }^{1}$ Prodi Kedokteran, Universitas Pendidikan Ganesha \\ ${ }^{2}$ Prodi Kedokteran, Universitas Pendidikan Ganesha \\ e-mail: narithya@undiksha.ac.id ,kurnia.widiastuti@undiksha.ac.id
}

\begin{abstract}
Abstrak
Postpartum hemorrhage merupakan penyebab kematian tertinggi pada ibu hamil utamanya pada negara berkembang. Hal ini disebabkan oleh berbagai kondisi yang di kelompokkan dalam $4 \mathrm{~T}$ yaitu tone, tissue, trauma, dan trombosis namun atoni uteri yang termasuk dalam kelompok tone menempati posisi teratas. Tingginya angka kematian di negara berkembang memiliki korelasi dengan penatalaksanaan manajemen aktif kala tika. Ketersediaan oksitosin dan uterotonikyang terbatas di berbagai wilayah menyebabkan manajemen aktif kala tiga tidak bisa dilakukan, hal ini berpotensi tinggi berujung pada postpartum hemorrhage. Di lain sisi, aspek kultur budaya, sosial, ekonomi, dan tingkat pendidikan dari masyarakat juga mempengaruhi tingkat mortalitas dari postpartum hemorrhage. Postpartum hemorrhage terjadi dengan cepat dan tak terprediksi sehingga klinisi harus segera menyadari saat hal ini terjadi. Hingga saat ini belum ada algoritma tatalaksana yang pasti terkait pencegahan postpartum hemorrhage namun kunci dari keberhasilan penanganan adalah identifikasi penyebab perdarahan yang akurat dan cepat. Identifikasi dari postpartum hemorrhage dapat dilakukan dengan Obstetric Shock Index (OSI), sistem pengukuran menggunakan Quantitative Blood Loss (QBL), dan The Rule of 30 . Penatalaksanaan terkait postpartum hemorrhage disesuaikan dengan kondisi dari ibu saat persalinan dan juga tahapan persalinan. Pasien dengan resiko postpartum hemorrhage akan mendapatkan tatalaksana yang berbeda baik pada kala satu, kala dua, dan kala tiga. Kunci dari pencegahan postpartum hemorrhage adalah dengan pemberian oksitosin dan uterotonik. Pencegahan dapat dilakukan dengan melakukan program pengenalan dan pemanfaatan fasilitas kesehatan serta melakukan manajemen aktif kala tiga
\end{abstract}

Kata kunci: Postpartum hemorrhage, kematian, ibu hamil

\begin{abstract}
Postpartum haemorrhage is the highest cause of death in pregnant women, especially in developing countries. It caused by various conditions which grouped into 4T such as tone, tissue, trauma, and thrombosis, but the atony that belongs to the tone group occupies the top position. The high rate of mortality in developing countries has correlation with the active management of third stage. The limited availability of oxytocin and uterotonics in various regions caused active management of the third stage can not be done and lead to postpartum haemorrhage. Moreover, cultural, social, economy, and education aspect of the community affected the mortality rate of postpartum haemorrhage. Postpartum haemorrhage occurs quickly and unpredictably so the clinicians must aware of the sign when this happens. For now, there is no definite management algorithm related to postpartum haemorrhage but the important thing is identification the etiology of bleeding correctly as soon as possible. Identification of postpartum haemorrhage can be done with Obstetric Shock Index (OSI), measurement system using Quantitative Blood Loss (QBL), and The Rule of 30. Management related to postpartum hemorrhage is adjusted to the condition of the mother during labour and also the stages of
\end{abstract}


labour. Patients at risk of postpartum haemorrhage will get different treatment both in the first, second and third stages. The key to prevent postpartum haemorrhage by giving oxytocin and uterotonics. Prevention can be done by conducting a program of introduction and utilization of health facilities and active management of the third stage.

Key Words: Postpartum hemorrhage, death, gravida

\section{PENDAHULUAN}

Postpartum hemorrhage (PPH) didefinisikan sebagai perdarahan dengan volume lebih dari $500 \mathrm{~mL}$ pada persalinan pervagina dan lebih dari $1000 \mathrm{~mL}$ pada persalinan perabdominal yang terjadi pasca persalinan. Kondisi ini dapat dievaluasi melalui adanya perubahan vital sign pada ibu berupa lemah, limbung, berkeringat dingin, menggigil, hiperapnea, tekanan darah sistolik < $90 \mathrm{mmHg}$, denyut nadi $>100 /$ menit, dan kadar $\mathrm{Hb}>8 \mathrm{~g} / \mathrm{dL}$ (Ghosh dan Chandraharan, 2017; Hikmah dan Yani, 2015; Kominiarek dan Kilpatrick, 2007). Kondisi ini sangat membahayakan, tidak terprediksi, dan muncul secara tiba tiba dengan prevalensi kasus sebanyak $19,7 \%$ di seluruh dunia. Penelitian menunjukkan bahwa PPH lebih banyak terjadi pada negara dengan tingkat ekonomi yang rendah dan terhitung sekitar 480.000 atau $32 \%$ kematian terjadi di Afrika Utara serta $8 \%$ kasus terjadi di negara berkembang (Kebede, et al., 2019).

Postpartum hemorrhage yang terjadi 24 jam pertama pasca persalinan di kelompokkan menjadi PPH primer sedangkan perdarahan yang terjadi antara 24 jam hingga 12 minggu pasca persalinan dikelompokkan menjadi PPH sekunder (Chandraharan dan Krishna, 2017). Etiologi dari PPH sendiri dikelompokkan menjadi empat kategori yaitu tone, tissue, trauma, dan thrombin dengan etiologi terbanyak adalah atoni uterina. Postpartum hemorrhage terjadi pada $4 \%$ hingga $6 \%$ kehamilan dengan $75 \%$ hingga $90 \%$ diantaranya disebabkan oleh atoni uterina. Sayangnya, faktor yang berkontribusi akan terjadinya PPH masih belum sepenuhnya dapat dipahami akibat deteksi yang masih bias dan subjektif, namun penelitian menunjukkan bahwa $68 \%$ dari postpartum hemorrhage yang berulang terjadi dengan penyebab yang sama sehingga dipastikan ada faktor resiko yang sama sebagai pencetusnya (Girard, et al., 2014; Kominiarek dan Sarah, 2007.). Mortalitas dan morbiditas PPH dipengaruhi oleh penilaian yang subjektif terkait jumlah darah yang hilang pada ibu pasca persalinan sehingga penting dilakukan pengukuran yang pasti terkait jumlah darah yang hilang agar identifikasi tidak bias. Selain itu, beberapa faktor terkait penyebab dari kematian pada kasus PPH telah diidentifikasi sebagai berikut: (Girard, et al., 2014).

(1). Penanganan yang terlambat akibat estimasi kehilangan darah yang salah

(2). Terlambat pemberian produk darah

(3). Algoritma penanganan yang tidak tepat

(4). Penangan dan pengetahuan yang kurang baik

(5). Komunikasi yang kurang baik

(6). Pengaturan yang kurang baik

The World Health Organization menyebutkan bahwa kematian akibat postpartum hemorrhage sendiri dapat dicegah dengan pemberian uterotonic profilaksis serta manajemen yang tepat sebagai contoh protokol pemberian tranfusi darah. Intervensi terhadap resiko postpartum hemorrhage berfokus pada persalinan kala tiga dengan melakukan manajemen aktif persalinan kala tiga (WHO, 2012). Faktor resiko dari postpartum hemorrhage dapat diidentifikasi pada saat antepartum maupun intrapartum sehingga perlu dilakukan perencanaan persalinan yang baik. Klinisi juga harus memperhatikan perdarahan yang terjadi pasca persalinan walau jumlah darah yang hilang kurang dari $1000 \mathrm{~mL}$ khususnya pada pasien dengan kondisi anemia sebelumnya dapat berdampak pada ketidakstabilan hemodinamik. Resusitasi cairan juga harus segera diberikan dalam 
satu jam pertama sebelum perdarahan mencapai sepertiga dari total darah yang beredar dalam tubuh dengan menghitung berat badan dikali 100 sebagai jumlah total darah yang beredardalam tubuh. Oleh karena itu, penggunaan batas perdarahan yang tidak berdasar seperti 1 hingga 2liter akan membahayakan nyawa dari ibu (Ghosh dan Chandradahan, 2017).

Berdasarkan data diatas, postpartum hemorrhage memiliki tingkat urgensi yang tinggi dengan morbiditas dan mortalitas yang tinggi pula. Sehingga diperlukan algoritma pencegahan dan penanganan yang baik untuk menekan kematian akibat postpartum hemorrhage.

\section{HASIL DAN PEMBAHASAN}

Negara maju dan negara industri memiliki prevalensi kasus PPH yang lebih baik dibandingkan dengan negara berkembang. World Health Organization (WHO) dalam WHO Recommendation for Prevention and Treatment of Postpartum hemorrhage menyebutkan bahwa sampai saat ini postpartum hemorrhage mejadi salah satu penyebab utama kematian ibu hamil di negara-negara berkembang. Analisis WHO menyebutkan bahwa negara berkembang memiliki prevalensi sebesar $16 \%$ hingga 27\% kematian akibat $\mathrm{PPH}$ sedangkan Amerika sebagai negara maju memiliki prevalensi $11 \%$ di tahun 2006 hingga 2011 (Papazian dan Kacmar, 2017). Angka PPH ketika manajemen aktif dilakukan dengan perdarahan lebih dari 500 $\mathrm{mL}$ terjadi sebanyak 5\% dibandingkan dengan persalinan tanpa manajemen aktif sebesar 13\%. Sedangkan data $\mathrm{PPH}$ dengan perdarahan lebih dari $1000 \mathrm{~mL}$ dengan manajemen aktif memiliki prevalensi $1 \%$ dan $3 \%$ dengan manajemen kehamilan tanpa manajemen aktif. Pada negara berkembang, manajemen kehamilan tanpa manajemen aktif masih sedikit di lakukan akibat kurangnya ketersediaan obat oksitosin. (Medscape, 2018). Michelle dan Sarah (2007) menyatakan bahwa dari 12.243 wanita dengan persalinan prevaginal, didapatkan persentase kasus postpartum hemorrhage sebesar $8,1 \%$ dan pada kasus yang rekuren $68 \%$ memiliki penyebab yang sama dengan postpartum hemorrhage sebelumnya. Saat ini, Afrika menjadi benua dengan tingkat kematian tertinggi akibat postpartum hemorrhage. Dalam penelitian yang berjudul Prevalence and Predictors of Primary Postpartum hemorrhage: An Implication for Designing Effective Intervention at Selected Hospitals, Southern Ethiopia dilakukan analisis terhadap 422 ibu hamil. Data penilitian menunjukkan bahwa kasus postpartum haemorrhage sebesar $83,9 \%$ terjadi pada umur 20-34 tahun namun ibu dengan usia lebih dari 35 tahun memiliki resiko $\mathrm{PPH}$ tujuh kali lebih tinggi dibandingkan pada kelompok umur 20 hingga 34 tahun. Prevalensi sebesar 57,1\% kasus pada ibu dengan tingkat pendapatan kurang dari 1000 Ethiopian birr (ETB) menegaskan bahwa tingkat ekonomi menjadi faktor penting terjadinya PPH. Dari segi pendidikan, 74,9\% kasus terjadi pada ibu dengan tingkat pendidikan selesai di tingkat 8 atau kurang. Penelitian ini menunjukkan data secara kuantitatif bahwa aspek ekonomi, usia, dan juga tingkat pendidikan sangat mempengaruhi mortalitas dan morbiditas postpartum haemorrhage (Kabede, et al., 2019)

Penyebab Postpartum hemorrhage dapat dikelompokkan menjadi 4T yaitu tone, tissue, trauma, dan trombosis (Tabel 1). 
Tabel 1: 4T Etiologi Postpartum hemorrhage (Kominiarek dan Kilpatrick, 2007)

\begin{tabular}{ll}
\hline Tone & Uterine atony \\
& Uterine inversion \\
\hline Tissue & Plasenta tertahan atau pembekuan darah \\
& Plesentasi abnormal (previa, accrete) \\
& Penyakit jaringan ikat (Ehlers-Danlos, Marfan) \\
\hline Trauma & Laserasi traktur genitalia bawah \\
& Ruptur uteri \\
& Hematoma \\
\hline Thrombosis & Koagulopati \\
& Penyakit koagulasi turunan \\
& HELLP \\
& DIC \\
& Penggunaan antikuagulan
\end{tabular}

Pada kelompok tone, PPH umumnya disebabkan oleh atoni uteri yang dibarengi dengan kegagalan dalam kontraksi dan retraksi miometrium dapat menyebabkan perdarahan yang cepat dan berat hingga terjadi syok hipovolemik. Hingga kini, atoni uteri menjadi penyebab paling sering postpartum hemorrhage dengan prevalensi kasus sekitar $80 \%$. Adanya distensi berlebih pada uterus menjadi penyebab utama terjadinya atoni uteri yang bisa terjadi akibat kehamilan multifetal, makrosomia janin, polihidramnion, atau kelainan janin seperti hidrosefalus berat, kelainan struktural uterus, maupun kegagalan untuk mengeluarkan plasenta atau distensi dengan darah sebelum atau setelah pengeluaran plasenta. Kegagalan kontraksi miometrium dapat pula dikarenakan kelelahan akibat persalinan yang terlalu lama, obat penghambat kontraksi seperti agen anestesi terhalogenasi, nitrat, obat antiinflamasi nonsteroid, magnesium sulfat, betasimpatomimetik, dan nifedipine. Penyebab lainnya dapat berupa implantasi plasenta di segmen bawah uterus, toksin dari bakteri oleh penyakit infeksi seperti korioamnionitis, endomiometritis, septicemia, hipoksia, dan hipotermia (Medscape, 2018). Uterus mendapat pasokan darah dari dua arteri uteri dan dua arteri ovari yang mengalirkan darah antara 500 hingga $900 \mathrm{~mL}$ per menit. Setelah persalinan selesai, terjadi peningkatan kadar oksitosin dan prostaglandin F2-alpha yang menyebabkan adanya kontraksi uterus dan vasokonstriksi. Kontraksi tonus otot uterus menjadi mekanisme primer pasca persalinan berlangsung dan apabila terjadi gangguan pada otot miometrium dalam berkontraksi akan berujung pada terjadinya postpartum hemorrhage. Hal ini dapat dicetuskan oleh beberapa hal seperti induksi persalinan, kelahiran perabdominal, augmentasi oksitosin, dan persalinan yang lama disebabkan oleh penurunan regulasi dari reseptor oksitosin dan penurunan kontraksi uterus. Polihidromnion, makrosomia, multiple pregnancy, dan multiparitas sebagai faktor pencetus terjadi akibat terganggunya interaksi aktin-myosin pada otot sedangkan korioamnitis disebabkan oleh inflamasi lokal yang terjadi pada jaringan kontraksi yang rusak. Tanpa alasan yang diketahui preeklamsia, obesitas, ras Hispanic, dan ras Kaukasian menjadi pencetus dari atonia uterine. Pada ibu yang diberikan medikasi berupa tokolitik seperti calcium channel blocker, magnesium, beta agonist, dan anastesi volatil dapat mengganggu kontraksi uterus (Collis dan Guasch, 2017; Papazian dan Kacmar, 2017)

Pada kelompok tissue, PPH berkaitan dengan pelepasan dan pengeluaran plasenta oleh kontraksi dan retraksi uterus. Retraksi lanjutan dan oklusi pembuluh darah akan optimal pada pelepasan plasenta secara menyeluruh sedangkan retensi dari pelepasan plasenta lebih sering terjadi pada plasenta dengan bentuk lobus succenturiate atau aksesoris. Plasenta pada kehamilan dengan masa preterm gestation kurang dari 24 minggu memiliki kemungkinan yang signifikan untuk terjadi perdarahan. Adanya plasenta yang tertahan memerlukan intervensi pelepasan segara 
yang biasanya penanganan dilakukan melalui operasi. Penelitian juga menunjukkan bahwa pemberian uterotonic prostaglandine tidak memberikan dampak pada plasenta yang tertahan dan apabila usaha untuk melepaskan plasenta gagal dilakukan kemungkinan terjadi plasenta akreta. Pelepasan plasenta secara parsial sering terjadi pada plasenta akreta dan sejenisnya yang mana awalnya terjadi sedikit perdarahan namun menjadi perdarahan hebat akibat usaha dalam pelepasannya. Sedangkan pada pasien dengan plasenta previa harus diinformasikan mengenai resiko terjadinya $\mathrm{PPH}$ yang memungkinkan dilakukannya transfusi darah dan histeroktomi (Medscape, 2018; Papazian dan Kacmar, 2017).

Terjadinya postpartum hemorrhage dapat disebabkan oleh trauma pada traktus genitalia yang terjadi secara spontan maupun perlukaan yang dibuat untuk memudahkan jalan lahir. Pada persalinan caesarean menyebabkan jumlah perdarahan dua kali lipat dibandingkan dengan persalinan pervagina. Trauma dapat dalam bentuk laserasi di perineum, vagina, dan serviks pada persalinan pervagina. Derajat laserasi dinilai dari kedalamannya mulai dari derajat 1 hingga 4. Beberapa derajat laserasi dapat mempersulit sebesar 60\% dengan $80 \%$ diantaranya merupakan kasus ringan namun pada derajat 3 hingga 4 dapat membahayakan struktur disekitar traktus genitalia seperti uretra, arteri vagina, dan sfingter anal. Pada laserasi berat memerlukan intervensi bedah serta tranfusi darah (Medscape, 2018; Papazian dan Kacmar, 2017). Trauma lainnya adalah ruptur uteri yang biasanya terjadi pada ibu dengan riwayat persalinan perabdominal sebelumnya. Oleh karena itu, kebiasaan palpasi transvaginal pada bekas luka tidak lagi rekomendasikan. Setiap ibu hamil yang pernah menjalani prosedur hingga mangkibatkan gangguan pada dinding uterus, akan dianggap memiliki resiko terhadap ruptur uteri. Prosedur tersebut termasuk myomektomi, uteroplasti, reseksi ektopik kornu, dan perforasi uterus saat dilakukan laparotomi, histerektomi, biosi, dilatasi, kuretase, dan penempatan alat kontrasepsi intrauteri. Prevalensi dari terjadinya ruptur uteri sekitar $0,1 \%$ dengan faktor resiko utama riwayat persalinan caesarean dikarenakan adanya peningkatan resiko hingga 40 kali lipat dibandingkan dengan pasien bersalin pervaginal.

Pada percobaan persalinan melalui cesarean, tidak diperbolehkan pemberian prostaglandin diakibatkan insiden rupture uteri meningkat menjadi lebih dari $2 \%$ begitu pula dengan pemberian oksitosin dalam jumlah besar (Medscape, 2018; Papazian dan Kacmar, 2017). Kemungkinan terjadinya rupture uteri meningkat pada persalinan dengan kontraksi kuat dan lama terutama pada kasus chepalopelvic disproportion dan sudah diberikan prostaglandin atau oksitosin. Bentuk trauma lainnya adalah laserasi serviks yang sering terjadi akibat penanganan persalinan pervaginal menggunakan forceps atau vacuum. Penggunaan forceps atau vacuum tidak dapat dilakukan jika pelebaran serviks belum terjadi sepenuhnya sehingga penggunaan forceps ataupun vacuum dengan kondisi serviks yang belum membuka sempurna akan menyebabkan laserasi pada vagina. Pada kasus yang sangat jarang, serviks sengaja diiris pada posisi arah jarum jam 2 atau 10 untuk membantu persalinan janin dengan kepala yang terperangkap dalam posisi sungsang, sayatan ini disebut dengan sayatan Dührssen (Medscape, 2018)

Etiologi dari postpartum hemorrhage yang terakhir adalah thrombin. Pada periode pasca persalinan, adanya gangguan pada faktor koagulasi sesungguhnya tidak banyak mempengaruhi akibat dari mekanisme penghentian perdarahan melalui kontraksi dan retraksi dari uterus. Namun hal ini dapat berbahaya saat terjadi deposisi fibrin dan bekuan darah pada pembuluh darah pada saat beberapa jam hingga beberapa hari pasca persalinan. Trombositipenia dapat muncul akibat dari penyakit yang sebelumnya sudah diderita oleh ibu seperti idiopathic thrombocytopenic purpura, akibat dari sindrom HELLP (Hemolysis, Elevated Liver Enzym, and Low Platelet count), disseminated intravascular coagulation 
(DIC), dan sepsis. Hal ini biasanya telah terdeteksi sebelumnya namun kadang juga tidak teridentifikasi. Kondisi lain seperti familial hypofibrinogenemia dan von Willebrand disease juga patut dipertimbangkan (Medscape, 2018).

Untuk menekan prevalensi kematian akibat postpartum hemorrhage diperlukan evaluasi faktor resiko sebelum persalinan dilakukan ataupun saat antenatal care. Hal ini dilakukan untuk pencegahan dan terapi yang maksimal baik pada ibu hamil yang bergejala maupun ibu hamil yang tidak menunjukkan adanya resiko untuk mengalami postpartum hemorrhage (Collis \& Guasch, 2017). National Partnership for Maternal Safety dalam buku yang berjudul Safety Bundle on Obstetric Hemorrhage menyatakan bahwa evaluasi terhadap faktor resiko perdarahan harus dilakukan pada masa antepartum, intrapartum, dan postpartum sehingga dapat membuat perencanaan persalinan yang tepat bagi ibu hamil.

Beberapa faktor resiko mayor pemicu postpartum hemorrhage adalah plasenta previa atau plasenta yang menutupi jalan lahir bayi, plasenta akreta maupun previa dengan riwayat cesarean sebelumnya, rupture uteri, anemia berat, trombositopenia maupun koagulopati lainnya, perdarahan aktif saat datang ke rumah sakit, persalinan cesarean, hipertensi antenatal, maupun kelahiran prematur (Markley \& Carusi, 2019).

Tabel 2. Pembagian Faktor Resiko (Kominiarek dan Kilpatrick., 2007).

\begin{tabular}{ll}
\hline Tipe & Penyakit \\
\hline Non-recurring & Primigraviditas \\
\hline Macrosomia \\
\hline Polihidromnia \\
\hline Multiple gestation \\
\hline Persalinan yang lama \\
\hline Persalinan tahap tiga yang lama \\
\hline Chorioamnionitis \\
\hline Kelahiran melalui operasi \\
\hline Perdarahan antepartum \\
\hline Recurring & Fibroids \\
\hline Obesitas maternal \\
\hline Penyakit koagulasi \\
\hline Riwayar cesarean \\
\hline Penyakit medis ataupun genetic spesifik \\
\hline Grand multiparity \\
\hline Riwayat postpartum hemorrhage \\
\hline
\end{tabular}

Angka kematian ibu akibat postpartum haemorrhage utamanya di negara berkembang terjadi akibat berbagai kondisi. Tingginya angka anemia pada ibu hamil, menyebabkan jumlah darah yang hilang saat persalinan meningkat. Belum lagi kultur dan budaya di negara tertentu untuk melakukan persalinan di dukun beranak yang tergolong bukan tenaga profesional untuk mengenali tanda postpartum haemorrhage. Hal lainnya seperti saat dilakukan perujukan ke fasilitas kesehatan yang lebih besar tidak tersedia transportasi yang tersedia ataupun jarak tempuh yang cukup jauh. Dalam mekanisme perujukan ke fasilitas kesehatan yang lebih besar, ketidakhadiran pihak suami juga dapat menghambat. Faktor lainnya adalah ketidaksediaan fasilitas yang adekuat dalam penanganan maupun tenaga medis terlatih untuk melakukan tindakan (Walraven, 2008). Pembagian dari faktor resiko ini dapat dibagi menjadi faktor yang dapat menyebabkan postpartum hemorrhage berulang dan tidak.

Tingginya angka kematian dikaitkan dengan kurangnya akurasi dari estimasi darah yang telah hilang. Oleh karena itu, 
National Partnership for Maternal Safety merekomendasikan sistem pengukuran menggunakan Quantitative Blood Loss (QBL) menggantikan Visual Blood Loss Estimation (EBL). QBL dilakukan dengan melakukan pengukuran volumetric seperti menggunakan tabung hisap untuk mengumpulkan dan mengukur darah yang hilanh (Markley dan Carusi, 2019). Royal College of Obstetricians and Gynaecologists Green-top Guideline pada bagian postpart haemorrhage juga menyatakan bahwa diagnosis harus segera dilakukan secara sistematis langsung setelah persalinan. Hal ini penting dilakukan menghindari keterlambatan penanganan dalam upaya menjaga stabilitas haemostasis pemberian resusitasi pada ibu. Pada kehamilan aterm (usia kehamilan lebih dari 37 minggu) alirah darah ibu sekitar $1000 \mathrm{~mL}$ setiap menitnya dengan sirkulasi ke plasenta janin sekitar 200 $\mathrm{mL} / \mathrm{kg} / \mathrm{menit}$. Identifikasi dari partus dengan postpartum hemorrhage dapat menggunakan Obstetric Shock Index (OSI) dan The Rule of 30. Indeks ini merupakan angka dari denyut nadi dalam semenit dibagi dengan tekanan sistolik pada partus. Pada orang normal, indeks berkisar 0,5 hingga 0,7 namun saat kehamilan akan meningkat berkisar 0,7 hingga 0,9 dikarenakan denyut nadi meningkat sedangkan tekanan sistolik akan menurun. Saat perdarahan terus terjadi, maka tubuh akan mengkompensasi kehilangan darah sehingga OSI meningkat. Jika indeks menunjukkan $>1$ maka partus dapat diindikasikan mengalami postpartum hemorrhage dan perlu segera dilakukan resusitasi. Perkiraan jumlah darah yang hilang terdapat pada Tabel 3 (Chandarahan dan Krishna, 2017; Ghosh dan Chandraharan, 2017; Markley dan Carusi, 2019).

Tabel 3: Temuan Klinis pada Postpartum hemorrhage (Gosh dan Chandaran, 2017)

\begin{tabular}{|c|c|c|c|c|}
\hline $\begin{array}{l}\text { Volume } \\
\text { Darah }\end{array}$ & Denyut Nadi & $\begin{array}{l}\text { Tekanan } \\
\text { Darah } \\
\text { Sistolik }\end{array}$ & Tanda & Syok \\
\hline $\begin{array}{l}500-1000 \mathrm{~mL} \\
(10-15 \%\end{array}$ & 80-100 bpm & Normal & $\begin{array}{l}\text { Teraba } \\
\text { takikardi, } \\
\text { pening }\end{array}$ & Terkompensasi \\
\hline $\begin{array}{l}1000-1500 \mathrm{~mL} \\
(15-30 \%)\end{array}$ & $100-120 \mathrm{bpm}$ & $\begin{array}{l}\text { Turun } \\
\text { ringan }(80- \\
100 \mathrm{mmHg}\end{array}$ & $\begin{array}{l}\text { Lemas, } \\
\text { takikardi, } \\
\text { berkeringat }\end{array}$ & Ringan \\
\hline $\begin{array}{l}1500-2000 \\
(30-40 \%)\end{array}$ & $>120$ bpm & $\begin{array}{l}\text { Turun } \\
\text { sedang (70- } \\
80 \mathrm{mmHg})\end{array}$ & $\begin{array}{l}\text { elisah, pucat, } \\
\text { oliguria }\end{array}$ & Sedang \\
\hline $\begin{array}{l}2000-3000 \\
(>40 \%)\end{array}$ & $\begin{array}{l}>120 \text { bpm dengan } \\
\text { adanya kegagalan } \\
\text { myocardial sehingga } \\
\text { menimbulkan reduksi } \\
\text { paradoksial hingga } \\
\text { terjadi cardiac arrest }\end{array}$ & $\begin{array}{l}\text { Turun berat } \\
(50-70 \\
\mathrm{mmHg})\end{array}$ & $\begin{array}{l}\text { Pingsan, } \\
\text { anuria, sesak }\end{array}$ & Berat \\
\hline
\end{tabular}

The rule of 30 digunakan untuk mengukur tingkat keparahan dari perdarahan. Disaat partus kehilangan darah $>30 \%$ maka akan terjadi penurunan tekanna darah sstolik $>30 \mathrm{mmHg}$, peningkatan heart rate minimal 30 kali per menit, respiratory rate lebih dari 30 kali tarikan napas per menit, dibarengi dengan penurunan hematokrit atau hemoglobin lebih dari $30 \%$, dan penurunan kadar ekskresi urin menjadi kurang $30 \mathrm{~mL}$ per jam (Gosh dan Chandraharan, 2017). Jenis evaluasi lainnya melalui diagonostik Point of Care dengan tes viscoelastis berupa rotational thromboelastometry (ROTEM) dan thromboelastography (TEG). Tes diagnostik ini dapat mengevaluasi coagulation tests of platelet count, 
prothrombin time, partial thromboplastin time, dan fibrinogen level dengan cepat. ROTEM maupun TEG akan membantu tenaga medis dalam tatalaksana transfusi darah dan telah terbukti dalam penelitian untuk menekan mortalitas kasus. Keuntungan yang diberikan dengan tes ini adalah interpretasi dari berbagai parameter dapat muncul 2 hingga 10 menit sehingga tatalaksana dapat lebih cepat dilakukan

(Markley dan Carusi, 2019; Pacheco dan Saade, 2018).

Manajemen dari postpartum haemorrhage sebelumnya masih menggunakan faktor pembekuan dan obat prohaemostasis sebagai tatalaksana dan para klinisi menyadari bahwa deteksi dini dan tatalaksana yang tepat dapat mencegah mortalitas dari postpartum haemorrhage. Para ahli dari Austria, Jerman, dan Switzerland dengan spesialisasi di bidang obstetris, anastesi, dan hemostasis telah mengkompilasikan tatalaksana postpartum haemorrhage menjadi sebuah algoritma. Algoritma ini terdiri dari empat tahapan yang mana disetiap tahapnya memiliki gejala klinis, tatalaksana umum atau operatif, dan medika mantosa yang berbeda. Macphail dan Talks (2004) dalam artikel yang berjudul Massive post-partum haemorrhage and management of disseminated intravascular coagulation menyatakan bahwa tujuan dari manajemen postpartum haemorrhage adalah mengembalikan volume darah yang bersirkulasi dan menjaga perfusi jaringan serta mencapai homeostasis dengan menangani etiologi dari perdarahan maupun terapi dari komponen koagulopati. Adanya keterlambatan dalam penananganan akan berdampak pada hipoperfusi jaringan, gagal organ, dan disseminated intravascular coagulation (DIC) sehingga mortalitas dan morbiditas meningkat.

Manajemen tahap satu bertujuan dalam deteksi, monitoring, dan identifikasi dari penyebab perdarahan dan langsung memanggil konsultan obstetris serta menginformasikan kondisi partus kepada dokter anastesi. Tahap ini harus dilakukan dengan cepat dalam kurun waktu kurang dari 30 menit.
Mortalitas dari postpartum haemorrhage utamanya terjadi akibat diagnosis yang kurang akurat mengenai jumlah darah yang hilang pada partus. Sehingga sebelum tatalaksana postpartum haemorrhage dilakukan, penting bagi klinisi untuk mendiagnosis dengan tepat. Postpartum haemorrhage terjadi apabila partus mengalami blood loss lebih dari 500 $\mathrm{mL}$ darah dengan persalinan pervagina dan lebih dari $1000 \mathrm{~mL}$ darah pada persalinan perabdominal. Apabila pada tahap ini pasien dalam kondisi hemodinamik yang stabil, maka tatalaksana dapat langsung dilakukan ke tatalaksana tahap tiga.

Saat postpartum haemorrhage telah terdeteksi, partus minimal diberikan dua akses cairan intravena dan diambil sampel darah untuk mencari kecocokan terhadap produk darah yang akan diberikan. Langkah selanjutnya adalah penambahan volume intravena dan pemasangan kateter Foley. Jenis cairan yang diberikan hingga kini masih banyak perdebatan baik pemberian cairan kristaloid maupun cairan koloid. Disebutkan bahwa cairan koloid lebih berpengaruh pada volume intarvaskular namun memiliki kekurangan dimana cairan koloid dapat menghambat agregasi platelet serta berpengaruh pada kadar fibrinogen. Pemberian cairan intravena dalam jumlah besar juga memerlukan penghangatan sebelum diberikan kepada partus. Gosh dan Chandraharan (2017) dalam artikel berjudul Management of Post-partum Hemorrhage menyatakan bahwa postpartum haemorrhage dengan perdarahan minor (perdarahan sekitar 500$1000 \mathrm{~mL}$ ) tanpa adanya tanda klinis diberikan terapi cairan intravena menggunakan 14 gauge cannula, diberikan venpuncture darurat sebanyak $20 \mathrm{~mL}$, cek blood count, dan faktor koagulasi. Setiap 15 menit dilakukan pemeriksaan nadi, tekanan darah, dan respiratory rate. Lalu diberikan cairan kristaloid yang telah dihangatkan. Sedangkan tatalaksana awal pada postpartum haemorrhage mayor dengan jumlah darah yang hilang lebih dari 1000 $\mathrm{mL}$ dan ditemukan tanda syok

serta perdarahan yang persisten, diberikan oksigen 15 liter/menit. Selanjutnya dilakukan pengecekan sirkulasi dengan pemasangan dua 14 gauge cannula perifer. 
Pasien diposisikan terlentang dan dijaga kehangatannya. Resusitasi cairan diberikan 3,5 liter dengan pemberian awal $2 \mathrm{~L}$ isotonic crystalloid hangat kemudian sisanya bisa diberikan isotonic crystalloid tambahan maupun koloid (succinylated gelatin). Selanjutnya diberikan venepuncture $20 \mathrm{~mL}$ langsung sebanyak 4 unit, darah lengkap, faktor koagulasi seperti fibrinogen, dan fungsi dasar ginjal dan hati. Pemantauan nadi, tekanan darah, dan respiratory rate menggunakan oximeter, electrocardiogram, dan automated blood pressure recording. Suhu badan pasien juga harus di monitor tiap 15 menit. Pertimbangkan untuk monitoring arterial dan pindahkan ke ruang ICU yang selanjutnya di monitoring menggunakan kurva modified early obstetric warning score (MEOWS).

Pada manajemen tahap dua, tatalaksana bertujuan untuk antisipasi dan terapi kemungkinan koagulopati yang harus dilakukan dalam waktu 30 menit. Syarat dari penatalaksana tahap dua adalah terjadinya perdarahan berat namun memiliki hemodinamik yang stabil. Sehingga partus yang dalam kondisi hemodinamik yang tidak stabil, harus langsung diberikan tatalaksana tahap tiga.

Sesegera mungkin ahli anastesi datang ke ruang persalinan dan seluruh staf disiagakan untuk kemungkinan operasi darurat. Apabila ditemukan kecurigaan retensi plasenta, maka segera lakukan pengangkatan plasenta secara manual ataupun kuretase rahim. Partus pada kondisi ini memerlukan ketersediaan red blood cells pack, fresh frozen plasma, platelet, dan produk darah yang sesuai. Berdasarkan guideline oleh British Committee for Standards in Haematology, pertahan hemoglobin $>80 \mathrm{~g} / \mathrm{L}$, jumlah platelet $>50 \times 109 /$, Prothrombin Time (PT) dan activated partial thromboplastin time (aPTT) < 1,5 kali normal, dan fibrinogen $>2$ $\mathrm{g} / \mathrm{l}$. Kedaruratan darah berdasarkan atas jumlah darah yang hilang tertera pada tabel 4 (Macphail dan Talks, 2004). Pengobatan tahap dua berfokus pada manajemen atoni uterina, koagulopati, temperatur, dan stabilitas hemodinamik

Tabel 4: Keperluan darah (Macphail dan Talks, 2004).

\begin{tabular}{|c|c|c|}
\hline $\begin{array}{l}\text { Estimasi Darah Hilang pada } \\
\text { wanita dengan berat badan } \\
60 \mathrm{~kg}\end{array}$ & Derajat Urgensi & Kebutuhan \\
\hline $500-1000 \mathrm{~mL}(10-20 \%)$ & Siaga & 2 unit cross-match standar \\
\hline $\begin{array}{l}1000-1500(20-30 \%) \\
\text { perdarahan terkontrol }\end{array}$ & $\begin{array}{l}\text { Gawat (memerlukan } \\
\text { darah dalam } 1 \text { jam) }\end{array}$ & 6 unit cross-match \\
\hline $\begin{array}{l}1000-1500 \mathrm{~mL}(20-30 \%) \\
\text { dengan perdarahan aktif }\end{array}$ & \multirow[t]{2}{*}{$\begin{array}{l}\text { Sangat gawat } \\
\text { (memerlukan darah } \\
\text { dalam } 30 \text { menit) }\end{array}$} & \multirow[t]{2}{*}{$\begin{array}{l}6 \text { unit darah tipe spesifik atau } \\
\text { uncross-match atau darah } \\
\text { elektronik }\end{array}$} \\
\hline $1500-2500 \mathrm{~mL}(30-40 \%)$ & & \\
\hline $\begin{array}{l}>2500(>40 \%) \text { atau lebih } \\
\text { dengan kondisi tidak } \\
\text { merespon pada resusitasi } \\
\text { cairan }\end{array}$ & $\begin{array}{l}\text { Gawat darurat } \\
\text { (memerlukan darah } \\
\text { dalam } 15 \text { menit) }\end{array}$ & $\begin{array}{l}\text { 2-4 unit darah grup O RhD- } \\
\text { negatif dilanjutkan dengan } \\
\text { darah tipe spesifik atau darah } \\
\text { elektronik }\end{array}$ \\
\hline
\end{tabular}


Mengatasi atoni uteri pada partus dengan pemberian prostaglandin E2 analog yaitu sulprostone. Pemberian sulprostone harus didahului pemberian oksitosin pada manajemen tahap satu. Dosis dari sulprostone adalah $1500 \mu \mathrm{g}$ dakam 24 jam dan dosis awal sebanyak $500 \mu \mathrm{g}$ diberikan dalam 60 menit pertama. Perlu diperhatikan bahwa pemberian sulprostone memberikan efek samping berupa menggigil, mual dan muntah, demam, dan peningkatan resistensi perifer.

Secara fisiologis, seorang ibu hamil menjadi hiperkogulatif. Pemeriksaan laboratorium konvensional memiliki waktu analisis yang cukup lama, seperti pemeriksaan activated partial thromboplastin time (aPTT) dan international normalized ratio (INR) yang baru terlihat setelah 45 hingga 60 menit. Dengan berkembangnya teknologi, penggunaan thromboelastography (TEG) dan rotational thromboelastometry (ROTEM) dapat memeriksa koagulasi seluruh daran dan fibrinolisis dalam beberapa menit. Pada kehamilan, normal TEG memiliki amplitudo maksimal 64-86 $\mathrm{mm}$ dengan kekencangan gumpalan fibrin maksimal senilai 15-38 $\mathrm{mm}$. perubahan hemostasis pada postpartum haemorrhage terlihat pada penurunan konsentrasi fibrinogen sebesar $39 \%$, kekencangan gumpalan TEG menurun sebesar $20 \%$, dengan aPTT dan INR hanya 12 hingga $15 \%$.

Pada ibu hamil, trimester ketiga terjadi penurunan tingkat fibrinolysis namun saat persalinan akan kembali meningkat. Oleh karena meningkatkanya fibrinolysis pada ibu dapat mencetus terjadi postpartum haemorrhage sehingga perlu diberikan antifibrinolisis seperti asam traneksamat. Asam traneksamat merupakan inhibitor kompetitif perubahan plasminogen menjadi plasmin, obat ini telah di konfirmasi oleh The World Maternity Antifibrinolytic bahwa asam traneksamat menurunkan angka kematian pada postpartum hemorrha 3 jam pertama setelah persalinan. The American College of Obstetricians and Gynecologists juga merekomndasikan pemberian asam traneksamat sebagai pencegahan penanganan lini kedua pada postpartum haemorrhage apabila pemberian uterotonik tidak memberikan hasil. Pemberian asam traneksamat memberikan dampak yang signifikan berupa penurunan angka tindakan sekunder, kebutuhan transfusi darah, dan tindakan operasi ulang. Dosis asam traneksamat dianjurkan sebanyak $2 \mathrm{~g}$ dikarenakan rekomendasi saat ini berkisar 1 hingga 3 gr sehingga kelompok ahli menganjurkaan dosis rata-rata yaitu $2 \mathrm{gr}$. Selain pemberian asam traneksamat, pemberian tambahan suplemen fibrinogen baik dilakukan. Penelitian menunjukkan bahwa pemberian asam traneksamat 1 gr dikombinasikan dengan misoprostol $600 \mathrm{mg}$ bukal lebih efektif daripada oksitosin 10 IU intravena dalam mencegah postpartum haemorrhage dengan persalinan prevaginal. Pemberian obat traneksamat saja tidak terbukti efektif untuk mencegah postpartum haemorrhage namun terbukti berhasil pada persalinan caesarean dikombinasikan dengan ligase arteri uteri bilateral (Markley dan Carusi, 2019; Pacheco dan Luis, 2018) 
Penelitian menunjukkan bahwa semakin tinggi rasio pemberian red blood cells dengan fresh frozen plasma akan menurunkan tingkat mortalitas serta menurunkan kemungkinan intervensi lebih lanjut dengan tetap diberikan sulprotone. rasio red blood cells dengan fresh frozen plasma lebih dari 1:2 memiliki hasil yang baik terkait tingkat mortalitas namun disebutkan pula bahwa terdapat sedikit perbedaan rasio pada pasien dengan intervensi dan tanpa intervensi yaitu 1:1.2 dengan 1:1.6. Fresh frozen plasma yang sedikit kandungan faktor koagulasi tidak akan efektif jika diberikan pada pasien dengan koagulopati disertai dengan perdarahan akibat tidak ada atau hilangnya faktor kuagulasi, aktivasi koagulasi, dan, dan koagulasi dilusional.

Salah satu faktor penting dalam perdarahan massif adalah menurunnya kadar fibrinogen pada pasien. Kadar fibrinogen pada wanita normalnya sekitar 2.0-4.5 g/l dan secara fisiologi akan meningkat menjadi 4.5-5.8 g/l. Pada ibu hamil dengan postpartum haemorrhage yang berat ditemukan bahwa kadan fibrinogen dalam darah menurun dengan drastis namun berbagai penelitian membuktikan bahwa pemberian fibrinogen secara dini dapat menurunkan kebutuhan tranfusi darah sehingga pemberian fibrinogen dapat menjadi pilihan lain dari terapi utama. Apabila ditemukan kadar fibrinogen $<400 \mathrm{mg} / \mathrm{dl}$ pada saat postpartum maka klinisi harus waspada akan adanya potensi perdarahan. Jika kadar fibrinogen $<300 \mathrm{mg} / \mathrm{dl}$ diperlukan pemberian fresh frozen plasma, cryoprecipitate, dan red blood cells segera, sedangkan fibrinogen yang
<200 mg/dl memerlukan penggantian komponen (Clark, 2015).

Langkah selanjutnya adalah manajemen tahap tiga. Tujuan utama dari manajemen tahap tiga adalah untuk menghentikan perdarahan untuk sementara dan mejaga kestabilan hemodinamik dari pasien. Usaha penghentian perdarahan tidak hanya dengan obat-obatan, namun juga dengan kompresi uterus secara manual. Manuver Crede menggunakan satu tangan dengan menggenggam fundus uteri namun hal ini sulit dilakukan pada ibu hamil dengan obesitas atau kelebihan berat badan. Kompresi bimanual dilakukan dengan satu dangan ditempatkan secara intravaginal tepat di belakang serviks dan tangan lainnya diletakkan di perut pasien tepatnya pada fundus untuk "menjepit" rahim. Keuntungan dilakukannya kompresi bimanual adalah klinisi dapat memposisikan Rahim lebih ke depan kearah simfisis pubis lalu memberikan kompresi lebih lanjut, memampatkan segmen bawah, dan menempatkan arteri uteri dalam peregangan.lalu Penghentian perdarahan sementara dicapai dengan melakukan tamponade uterus hingga hemodinamik pasien stabil dan kuaogulopati tertangani. Teknik lainya untuk menghentikan postpartum haemorrhage untuk sementara adalah tamponade uteri. Tamponade dilakukan dengan menggunakan kasa ataupun tamponade balloon. Penggunaan kasa dalam tamponade selain dikarenakan murah dan mudah ditemukan, banyak literatul dan buku kedokteran yang merekomendasikan sejak tahun 1930an. Kasa dapat ditempatkan secara manual maupun menggunakan 
forsep panjang dan dimasukkan kasa hingga penuh dengan ujung kasa masih ada di luar uterus untuk mempermudah monitoring dan mengambilan kasa. Penelitian terbaru menyatakan bahwa penggunaan kasa yang telah di rendam kitosan lebih baik dalam mencapai haemostasis dibuktikan dengan kebutuhan histerektomi berkurang hingga $75 \%$. Keuntungan dari dilakukannya kompresi di dalam rongga uterus tidak hanya menghentikan perdarahan namun juga mengurangi aliran darah yang masuk ke arteri uteri dan menurunkan tekanan perfusi. Saat kestabilan hemodinamik pasien tercapai, pertimbangkan pasien untuk dirujuk ke fasilitas kesehatan yang lebih besar (Hill, et al., 2019).

Manajemen tahap empat dilakuan pada pasien dengan kegagalan penghentian perdarahan di manajemen tahap tiga. Pasien dengan perdarahan yang persisten memiliki kondisi hemodinamik yang tidak stabil, hipotermia, koagulopati, dan asidosis. Kondisi pasien dengan hemodinamik yang tidak stabil kemungkinan besar memerlukan operasi namun para ahli obstreti berpendapat bahwa dilakukannya operasi histerektomi harus dikaji dengan baik karena sangat beresiko. Selama operasi dilaksanakan, rata rata durasi yang dibutuhkan sekitar $157 \pm 75$ menit dengan total darah yang hilang sekitar $3325 \pm 1839 \mathrm{~mL}$. Oleh karena itu, algoritma yang dianjurkan sebagai berikut:

1. Fase 1: dilakukan laparotomi dengan insisi pfannenstiel maupun vertikal.

2. Fase 2: jeda operasi dan stabilkan pasien hingga kondisi hipovolemia, hipotermia, kuagulopati, dan asidosis membaik di ruang ICU maupun ruang operasi.

3. Fase 3: Lakukan operasi dan lakukan kompresi jahitan uterus dengan teknik jahit B-Lynch, ataupun Hayman.

Tindakan operasi dapat menurunkan aliran darah ke rahim sehingga darah yang keluar dapat dihentikan. Operasi dilakukan dengan menghambat aliran darah dari empat sumber yaitu arteri uteru bagian atas dan bawah dari ureter, arteri vagina cabang dari uterus, dan arteri ovari. Terapi ini tidak akan berdampak pada kehamilan maupun persalinan selanjutnya namun perlu diperhatikan struktur dari vaskularisasi itu sendiri untuk mencegah munculnya resiko. kompresi jahitan juga dapat dilakukan dengan tamponade internal menggunakan ballon catheter sehingga mudah untuk dipasang dan dilepaskan. Alternatif lainnya dapat menggunakan kondom yang diikat pada ujung kateter Foley dengan harga yang lebih murah. Ligasi pembuluh darah atau O'leary dilakukan dengan melakukan penjahitan melewati miometrium sekitar $2 \mathrm{~cm}$ medial dari ureter lalu diikat untuk memberi kompresi. Saat pasien sudah dalam kondisi stabil, pasien dapat diberikan terapi Utery Embolization Artery yang dapat menghentikan postpartum haemorrhage sekaligus menjaga kondisi kesuburan uterus jika material yang digunakan mudah diserap seperti gel foam. Metode ini telah dilaporkan sangat efektif dengan prevalensi $95 \%$ tanpa adanya efek samping di masa mendatang. Namun saat pasien tidak kunjung stabil, Histerektomi harus segera dilakukan. 
Penanganan ini tidak dapat menjaga uterus dan kesuburan dari pasien namun dapat mencegah mortalitas dan morbitasnya. Proses pembedahan dapat lebih cepat dilakukan apabila peralatan histerektomi berupa $O$ Ring Retractor digunakan. Sampai saat ini belum ada rekomendasi tetap mengenai histerektomi supraservikal (SCAH) ataupun histerektomi total $(\mathrm{TAH})$, keputusan ini di serahkan kepada ahli obstetrik dengan mempertimbangkan lokasi dan keparahan dari perdarahan. Histerektomi supraservikal dilakukan saat serviks edema mulai sejak kehamilan, dilatasi sulit dilakukan, dan pembuluh darah yang membesar sulit untuk diikat sehingga memungkinkan perdarahan yang lebih berat dan waktu operasi yang lebih lama. Saat histerektomi supraservikal telah ditetapkan, penting untuk memastikan tidak adanya jaringan plasenta maupun perdarahan dari serviks agar tidak ada resiko dilakukan operasi ulang untuk trachelectomy. Namun, pada kasus dengan invasi plasenta atau trauma servikal berat perlu dilakukan histerektomi total (Gilmandyar, et al., 2018).

The World Health Organization menyatakan bahwa setiap ibu berhak mendapatkan fasilitas kesehatan yang memadai saat masa mengandung, bersalin, maupun pasca persalin. Dilain sisi, faktor yang mempengaruhi mortalitas dna morbiditas postpartum haemorrhage sangat beragam dan mungkin saja tidak terdeteksi. Seorang wanita yang memiliki resiko rendah untuk terjadi postpartum haemorrhage bisa mengalami hal tersebut dengan onset cepat sehingga waktu menjadi terbatas untuk dirujuk ke fasilitas kesehatan yang lebih besar. Ibu hamil yang tidak melakukan antenatal care, memiliki peluang untuk memerlukan intervensi persalinan seperti tranfusi darah ataupun operasi yang tentu tidak bisa dilakukan oleh orang yang tidak di bidangnya. Oleh karena itu, berikut pencegahan yang dapat dilakukan pada kasus postpartum haemorrhage (Hofmeyr dan Qureshi, 2016)

Manajemen aktif kala tiga muncul saat oksitosin mulai banyak diberikan. Tujuan pemberian dari oksitosin adalah meningkatkan efektivitas dari kontraksi uterus dan mengontrol kontraksi dari tali pusat agar tidak terjadi plasenta tertahan. Penelitian menunjukkan bahwa manajemen aktif kala III dapat mencegah terjadinya postpartum haemorrhage dan kini menjadi tatalaksana standar dalam persalinan di seluruh dunia. Manajemen aktif kala III dapat mengurangi pengeluaran darah hingga $50-70 \%$ dibandingkan dengan manajemen persalinan biasa. The World Health Organization (WHO), The UK National Institute for Health and Care Excellence (NICE), dan International Federation of Gynecology and Obstetrics (FIGO) merekomendasikan oksitosin dan carbetocin sebagai profilaksis dari postpartum haemorrhage. Penanganan ini dilakukan saat bayi ataupun plasenta baru saja lahir. Pemberian oksitosin setelah persalinan bayi maupun plasenta tidak memberikan perbedaan hasil yang signifikan yaitu $5,4 \%$ dibandi 5,8\%.Pemberian dilakukan melalui intramuskular namun juga dapat diberikan intravena secara berlahan dikarenakan dapat menurunkan tekanan darah yang 
signifikan. Pemberiaan oksitosin intravascular dan intramuscular tidak memberikan dampak yang signifikan, pada kasus postpartum haemorrhage $>500 \mathrm{~mL}$ EBL prevalensi menunjukkan $19 \%$ versus $23 \%$ sedangkan kasus postpartum haemorrhage berat memiliki hasil yang cukup berbeda yaitu $5 \%$ vs $8 \%$ dengan kebutuhan transfusi $1,5 \%$ vs $4,4 \%$. Dalam berbagai metaanalisis, pemberian agen uterotonik dalam pencegahan postpartum haemorrhage sangat efektif dibandingkan placebo ataupun tanpa pengobatan. Rekomendari dari The World Health Organization (2012), oksitosin menjadi uterotonik utama yang diberikan, apabila tidak tersedia dapat diberikan ergometrine atau methylergometrine atau misoprostol oral $600 \mu \mathrm{g}$. Pada kondisi persalinan tanpa ahli obstetric dan tidak tersedia oksitosi, pasien diberikan misoprostol peroral $600 \mu \mathrm{g}$ oleh tenaga kesehatan (Weeks, 2014; Kominiarek dan Kilpatrick, 2007; Markley dan Carusi, 2019 ).

Budaya di negara berkembang banyak dipengaruhi oleh kepercayaan untuk melakukan persalinan di dukun tradisioanl yang tentu bukanlah tenaga professional dalam penanganan persalinan. Budaya yang kental terutama di daerah yang belum banyak berkembang menyebabkan ibu bersalin dalam kondisi yang tidak ideal seperti tidak dalam ruang dan peralatan steril, minim pengetahuan dari penolong bersalin, dan transportasi padahal WHO menyatakan bahwa setiap ibu berhak untuk mendapatkan fasilitas kesehatan yang layak baik saat. Tingkat Pendidikan ibu yang masih rendah menyebabkan ibu tidak mengetahui tempat yang tepat untuk mendapat informasi mengenai persalinan sehingga hal ini terus berkembang di masyarakat. Informasi yang memadai kepada ibu yang akan bersalin akan memberikan pemahaman kepada ibu dan keluarga bahwa persalinan di fasilitas kesehatan memiliki resiko kecil. Tingkat pendidikan juga mempengaruhi kemampuan penafsiran ibu terkait informasi kesehatan yang diberikan. Sebagai contoh seorang wanita melakukan konsultasi rutin antenatal care dan tidak ditemukan masalah saat persalinan malah membuat ibu tidak memilih melahirkan di fasilitas kesehatan. Pada aspek lainnya, biaya yang diperlukan untuk melakuakn persalinan termasuk biaya transportasi dan biaya tidak langsung menjadi kendala pada kelompok masyarakat berpendapatan rendah. Penelitian melaporkan bahwa pemanfaatan dari fasilitas menurun saat biaya yang diperluka di informasikan kepada ibu dan keluara. Oleh karena itu, beban biaya menjadi salah satu faktor utama ibu tidak melakukan antenatal care dan juga persalinan di fasilitas kesehatan.

Berbagai intervensi dilakukan berupa Pendidikan masyarakat, fasilitas transportasi, dan pelatihan dukun di Indonesia, Nigeria, dan Bolivia. Data menunjukkan bahwa intervensi ini meningkatkan pemanfaatan fasilitas kesehetan. Di India diberlakukan program "Asha" yang melatih masyarakat mengenai kesiapan persalinan dan pendampingan ibu ke fasilitas kesehatan. Hasilnya menunjukkan pengurangan waktu yang diperlukan untuk mencapai fasilitas kesehatan. Intervensi yang penting dilakukan adalah terkait biaya 
persalinan telah dilakukan oleh pemerintah Republik Kongo. Program yang dilakukan berupa promosi persalinan tanpa dipungut biaya bagi masyarakat kurang mampu ataupun biaya disesuaikan dengan kemampuan ekonomi keluarga bersangkutan. Hal ini berdampak pada peningkatan persalinan hingga tujuh kali lipat pada kelompok masyarakat kurang mampu yang mengikuti program dibandingkan dengan yang tidak (Walraven, 2008).

\section{KESIMPULAN}

Postpartum hemorrhage memiliki tingkat morbiditas dan mortalitas yang tinggi utamanya di negara berkembang dengan prevalensi sebesar $16 \%$ hingga $27 \%$ kematian akibat PPH sedangkan Amerika sebagai negara maju memiliki prevalensi 11\% hingga tahun 2011 (Papazian dan Kacmar, 2017). Hal ini banyak dipengaruhi oleh manajemen aktif yang tidak bisa dilakukan akibat dari kurang ketersediaan oksitosin. Data penilitian menunjukkan bahwa kasus postpartum haemorrhage sebesar $83,9 \%$ terjadi pada umur 20-34 tahun namun ibu dengan usia lebih dari 35 tahun memiliki resiko PPH tujuh kali lebih tinggi dibandingkan pada kelompok umur 20 hingga 34 tahun. Namun faktor lain seperti tingkat pendidikan dan ekonomi banyak mempengaruhi angka kasus postpartum haemorrhage (Kabede, et al., 2019).

$$
\text { Etiologi dari postpartum }
$$
haemorrhage dibagi menjadi empat yaitu tone, tissue, trauma, dan thrombin. Prevalensi mortalitas sebesar $80 \%$ disebabkan oleh atoni uteri yang masuk ke dalam kelompok tone. Atoni uteri terjadi akibat adanya distensi dari otot myometrium yang dibarengi dengan kegagalan kontraksi dan retraksi miometrium. Adanya retensi plasenta saat persalinan dapat menyebabkan adanya perdarahan utamanya pada bentuk plasenta succenturiate atau aksesoris. Perlukaan yang dibuat untuk mempermudah persalinan juga mempengaruhi jumlah darah yang hilang. Persalinan perabdominal menyebabkan perdarahan yang lebih hebat dibandingkan persalinan prevaginal dengan jumlah darah yang hilang hingga $1000 \mathrm{~mL}$. Etiologi terakhir yaitu thrombin disebabkan oleh kondisi dari ibu yang kekurangan faktor koagulasi utamanya pada kondisi deposisi fibrin dan bekuan darah pada pembuluh darah pada saat beberapa jam hingga beberapa hari pasca persalinan.

Faktor resiko dari postpartum haemorrhage menjadi mematikan akibat tidak dilakukannya peemriksaan rutin untuk mendeteksi hal tersebut. Kultur dan budaya masyarakat utamanya pada negara berkembang yang belum banyak memanfaatkan fasilitas kesehatan mempengaruhi tingkat kematian akibat postpartum hemorrhage. National Partnership for Maternal Safety menyatakan bahwa evaluasi terhadap faktor resiko postpartum hemorrhage harus dilakukan pada antepartum, intrapartum, dan postpartum sheingga mortalitas dan morbiditas pada ibu dapan ditekan. Hal lainnya seperti saat dilakukan perujukan ke fasilitas kesehatan yang lebih besar tidak tersedia transportasi yang tersedia ataupun jarak tempuh yang cukup jauh. Dalam mekanisme perujukan ke 
fasilitas kesehatan yang lebih besar, ketidakhadiran pihak suami juga dapat menghambat. Faktor lainnya adalah ketidaksediaan fasilitas yang adekuat dalam penanganan maupun tenaga medis terlatih untuk melakukan tindakan (Walraven, 2008).

Postpartum haemorrhage dapat terjadi dengan cepat dan tak terprediksi sehingga klinisi harus dapat segera menyadari jika hal itu terjadi. Diagnosis dapat dilakukan menggunakan Obstetric Shock Index (OSI), The Rule of 30, dan diagnostik Point of Care. Diagnosis dengan Obstetric Shock Index membagi denyut nadi dalam semenit dengan tekanan sistolik jika hasil >1 maka pasien diindikasikan mengalami postpartum haemorrhage (Chandarahan dan Krishna, 2017; Ghosh dan Chandraharan, 2017; Markley dan Carusi, 2019). Metode diagnosis lainnya adalah The Rule of 30 yang menilai dari kondisi pasien. Kriteria postpartum haemorrhage dengan metode ini adalah penurunan tekanan darah $>30 \mathrm{mmHg}$, peningkatan heart rate minimal 30 kali per menit, respiratory rate lebih dari 30 kali tarikan napas per menit, dibarengi dengan penurunan hematokrit atau hemoglobin lebih dari $30 \%$, dan penurunan kadar ekskresi urin menjadi kurang $30 \mathrm{~mL}$ per jam (Gosh dan Chandraharan, 2017). Sedangkan diagnostik dengan metode Point of Care dilakukan menggunakan viscoelastic test yaitu ROTEM dan TEG. Tes diagnostik ini dapat mengevaluasi coagulation tests of platelet count, prothrombin time, partial thromboplastin time, dan fibrinogen level dengan cepat (Markley dan Carusi, 2019; Pacheco dan Saade, 2018).
Manajemen dari postpartum hemorhage harus dilakukan secara cepat oleh klinisi untuk mencegah mortalitas. Algoritma ini terdiri dari empat tahapan yang mana disetiap tahapnya memiliki gejala klinis, tatalaksana umum atau operatif, dan medika mantosa yang berbeda. Tujuan dari manajemen postpartum haemorrhage adalah mengembalikan volume darah yang bersirkulasi dan menjaga perfusi jaringan serta mencapai homeostasis. Apabila penanganan terlambat diberikan akan berdampak pada hipoperfusi jaringan, gagal organ, dan disseminated intravascular coagulation (DIC). Manajemen tahap satu bertujuan dalam deteksi, monitoring, dan identifikasi dari penyebab perdarahan sedangkan manajemen tahap dua bertujuan untuk antisipasi dan terapi kemungkinan koagulopati. Tujuan utama dari manajemen tahap tiga adalah untuk menghentikan perdarahan untuk sementara dan mejaga kestabilan hemodinamik dari pasien dan apabila perdarahan tetap berlangsung akan dilanjutkan ke manajemen tahap empat.

Pencegahan dari postpartum haemorrhage dapat dilakukan dengan melakukan manajemen aktif kala III saat persalinan dengan menggunakan oksitosin dan carbetocin. Di lain sisi, aspek kultur budaya, sosial, ekonomi, dan pendidikan masyarakat sangat mempengaruhi. Budaya masyarakat khususnya di negara berkembang lebih memilih persalinan di dukun tradisional. Biaya yang tinggi juga menyebabkan pemanfaatan fasilitas kesehatan menurun serta pendidikan masyarakat yang rendah menyebabkan masyarakat 
tidak tahu harus mendapatkan informasi kesehatan dari mana.

\section{DAFTAR PUSTAKA}

Chandraharan, E., \& Krishna, A. (2017). Diagnosis and management of postpartum haemorrhage. thebmj.

Clark, S. (2015). Obstetric hemorrhage-Expert opinion. Seminars in Perinatology.

Collis, R., \& Guasch, E. (2017). Managing major obstetric haemorrhage: Pharmacotherapy and transfusion. Best Practice \& Research Clinical Anaesthesiology.

Drew, T., \& Balki, M. (2019). What does basic science tell us about the use of uterotonics? est Practice \& Research Clinical Obstetrics and Gynaecology.

Ghosh, M., \& Chandraharan, E. (2017). Management of post-partum haemorrhage . Obstetrics, Gynaecology, and Reproductive Medicine.

Gilmandyar, D., \& Thornburg, L. (2018). Surgical Management of Postpartum Hemorrhage. Seminars in Perinatology.

Girard, T., Mo rttl, M., \& Schlembach, D. (2014). New approaches to obstetric hemorrhage: the postpartum hemorrhage consensus algorithm. Obstetric and gynecological anesthesia.

Hikmah, N., \& Yani, D. (2015). GAMBARAN HEMORAGIC POST PARTUM PADA IBU BERSALIN DENGAN KEJADIAN ANEMIA DI RUANG
PONEK RSUD KABUPATEN JOMBANG. JURNAL EDUHEALTH.

Hill, A., Fox, K., \& Martin, S. (2019). Postpartum hemorrhage. Evidence-Based Obstetrics and Gynecology.

Hofmeyr, G., \& Qureshi, Z. (2016). Preventing deaths due to haemorrhage. Best Practice \& Research Clinical Obstetrics and Gynaecology.

Kebede, B., Abdo, R., Anshebo, A., \& Gebremariam, B. (2019). Prevalence and predictors of primary postpartum hemorrhage: An implication for designing effective intervention at selected hospitals, Southern Ethiopia. PLoS ONE.

Kominiarek, M., \& Kilpatrick, S. (2007). Postpartum Hemorrhage: A Recurring Pregnancy Complication. Seminars in Perinatology.

Macphail, S., \& Talks, K. (2004). Massive post-partum haemorrhage and management of disseminated intravascular coagulation. Current Obsterics \& Gynaecology.

Markley, J., \& Carusi, D. (2019). Postpartum Hemorrhage: What s New? Current Obstetrics and Gynecology Reports.

Organization, W. H. (2017, Juni 15). WHO Recommendations on Prevention and Treatment of Postpartum Haemorrhage and the WOMAN Trial. Retrieved from www.who.int: https://www.who.int/reproductive health/topics/maternal perinatal /pph-woman-trial/en/ 
Pacheco , L., \& Saade , G. (2018). Medical Management of Postpartum Hemorrhage: An Update. Seminars in Perinatology.

Papazian, J., \& Kacmar, R. (2017). Obstetric Hemorrhage Prevention, Recognition, and Treatment. ADVANCES IN ANESTHESIA.

Smith, J. R. (2018 , Juni 27). Postpartum Hemorrhage. Retrieved from emedicine.medscape.com: https://emedicine.medscape.co m/article/275038-overview\#a7

Walraven, G. (2008). Management of post-partum hemorrhage in lowincome countries. Best Practice \& Research Clinical Obstetrics and Gynaecology.

Weeks, A. (2014). The prevention and treatment of postpartum haemorrhage: what do we know, and where do we go to next? BJOG.

Yiadom, M. Y. (2018, Januari 02). Postpartum Hemorrhage in Emergency Medicine. Retrieved from emedicine.medscape.com: https://emedicine.medscape.co m/article/796785-overview 